\title{
Energy and Economic Analysis of Life Cycle Zero Energy Building in the Temperate Region
}

\author{
Zhiyong ZHOU, Xiaochen ZHANG, Jia LU, Jiangang HUANG, Li ZHOU, Yiqin HE
}

\begin{abstract}
Life cycle zero energy buildings (LCZEBs) can present energy use more accurately than net zero energy buildings (NZEBs). Economic benefits are crucial for residents to accept LCZEBs. However, few relevant case studies have been conducted. A comparative analysis between a NZEB and a LCZEB with a multi-story apartment in a temperate region that meets the requirements of local building energy codes as the reference building was conducted in this study to ascertain economic feasibility of LCZEB. First, a building model and an energy model were established on the basis of site test, survey, and monitoring data. Then, the energy balances of the NZEB and LCZEB were calculated on the basis of the results of energy simulation and the foregoing data. Finally, the LCZEB and NZEB were realized on the condition that high thermal performance materials and high energy efficiency building equipment were adopted in accordance with the principle of maximizing net present value (NPV) and solar energy was fully utilized. Results demonstrate that solar hot water and photovoltaic systems are critical to the NZEB and LCZEB. Annual net energy (ANE) and annual NPV per square meter of thermal collector are $-571.11 \mathrm{kWh}$ and $\$ 455.5$, respectively, and ANE and annual NPV per square meter of photovoltaic panel are $-115.62 \mathrm{kWh}$ and $\$ 13.2$. The NZEB and LCZEB are economically feasible in the temperate region although the NZEB is superior to the LCZEB in terms of economic benefits. Their NPVs for the calculation period (20 years) are $\$ 15369.64$ and $\$ 4718.77$, and their payback periods are 11 and 16 years. This study can provide references for energy and economic optimization of NZEBs and LCZEBs.
\end{abstract}

Keywords: life cycle zero energy buildings; net zero energy buildings; embodied energy

\section{INTRODUCTION}

Considerable evidence has demonstrated that the accumulation of greenhouse gases in the atmosphere is an important cause of global warming, and building energy use is a major contributor to greenhouse gas emissions [1]. Commercial and residential buildings in the United States consume around $40 \%$ of the primary energy and $70 \%$ of the electricity, whereas buildings account for $40 \%$ of total energy use in the European Union (EU) [2]. The ratio of building energy use (including construction and operation) to the total energy use in China is $44.9 \%$ [3]. Huge building energy consumption poses two threats- energy safety and environmental pollution [4]. Hence, many countries have proposed mandatory requirements for the lowest energy performance of new buildings to reduce building energy use. Scholars have strived to find high energy-efficiency measures to improve the energy performance of buildings. Passive house, a typical low-energy building, is the result of the effort, which is a facultative certification scheme initiated by the PassiveHau Institute in the beginning of 1990s [5]. The first passive house was built in 1991 in Darmstadt-Kranichstein, Germany. Heating or air conditioning load of passive house is generally lower than $10 \mathrm{~W} / \mathrm{m}^{2}$ [6]. A passive house can be considered a highly insulated and airtight building in which the heating load is so low as to rely solely on a mechanical ventilation system for heating delivery [7]. The principles of high insulation, good air tightness, and heat recovery ventilation systems are followed by most voluntary certifications for lowenergy buildings.

However, low-energy building is only a good first step toward zero energy building (ZEB) because these solutions generally use lower quantities of material and equipment than extreme zero energy solutions [8]. Therefore, the EU regulated that all new buildings of all EU member states should be net ZEBs $\left(\mathrm{NZEB}_{\mathrm{S}}\right.$ ) by December 31, 2020. In addition, the California Public Utilities Commission has an energy action plan to achieve net zero energy for all new residential constructions by 2020 and net zero for all new commercial constructions by 2030 [9]. In general, the ZEB can be an autonomous building, which does not interact with any external energy supply system (grid). Meanwhile, the NZEB may be a building where the weighted supply of energy from the building meets or exceeds the weighted demand and interacts with an energy supply system (grid) [10]. This may be attributed to the new technologies applied in smart grids such as energy hubs [11]. However, neither ZEB nor NZEB consider the embodied energy and the energy use for the maintenance and demolition of the building. Thus, several scholars have proposed life cycle ZEB (LCZEB) that includes the embodied energy of the building and its components together with annual energy use (AEU) [8].

After the implementation of energy-saving measures, the energy use per unit floor area of a multi-story apartment in Kunming, China, a typical city in the temperate region, is $40.67 \mathrm{kWh} /\left(\mathrm{m}^{2} \cdot \mathrm{a}\right)$ [12], which can meet the requirements of German passive houses [5]. Specifically, the energy use for heating or air conditioning is $\leq 11.9 \mathrm{kWh} /\left(\mathrm{m}^{2} \cdot \mathrm{a}\right)$, energy use for water heating is $\leq 6.1 \mathrm{kWh} /\left(\mathrm{m}^{2} \cdot \mathrm{a}\right)$, energy use for cooking is $\leq 2.6 \mathrm{kWh} /\left(\mathrm{m}^{2} \cdot \mathrm{a}\right)$, and other power consumptions (including energy consumption of appliances $)$ are $\leq 11.2 \mathrm{kWh} /\left(\mathrm{m}^{2} \cdot \mathrm{a}\right)$. Apparently, apartments in the temperate region have many advantages to realize NZEB and LCZEB. Thus, the economic feasibility of NZEB and LCZEB is discussed by taking a multi-story apartment in Kunming, China as a sample.

\section{STATE OF THE ART}

Many case studies have been reported on NZEB. Iqbal [13] showed that the energy use of a typical R-2000 house in Newfoundland recorded on site can be counteracted by the power generated by a wind power system. Wang, Gwilliam, and Jones [14] reported that a domestic house in the UK with passive building design can meet the requirements of NZEB after installing a solar thermal system for hot water and heating and a photovoltaic system to supply power. A typical detached house in Tehran with Trombe wall, roller shading, fiber optics, a solar thermal system, and a photovoltaic system can realize NZEB with 
a payback period (PP) of 10 years [15]. Pikas, Thalfeldt, Kurnitski, and Liias [16]stated that the NZEB will cost $4 \%-7 \%$ more than the existing buildings. In China, several scholars have conducted several studies on NZEB. Tian [17] and Sun [18] discussed the design of NZEB. Li [19] found that a three-floor residential building with solar photovoltaic system can realize ZEB. Feng, Xu, and $\mathrm{Wu}$ [20] elaborated the adopted energy-saving measures of a NZEB demonstration project in China although the energy balance was absent. However, all the above-mentioned studies solely consider the energy use in the operational stage of buildings.

To address this limitation, scholars have investigated the life cycle energy use (LCEU) of NZEB. Stephan and Stephan [21] used an apartment in Lebanon as a sample to quantify the LCEU and cost requirements associated with 22 different energy reduction measures targeting embodied, operational, and user-transport requirements. However, the portfolio strategy of these measures for LCZEB is inaccurate. Berggrenaea al. [10] concluded that the LCEU of NZEB is $60 \%$ lower than that of low-energy building. However, realization of LCZEB was not discussed. According to the research of Leckner and Zmeureanu [22], the embodied energy for a NZEB of twostory house in Montreal, Canada is $521,300 \mathrm{kWh}$, and the operating energy minus power generated by the photovoltaic system on site is $-1,100,700 \mathrm{kWh}$, which implies that the NZEB is unqualified as a LCZEB because the embodied energy cannot be offset. Atmaca and Atmaca [23] confirmed that the LCEU of residential buildings in urban areas is higher than that in rural areas. However, the path to reach zero energy from the aspects of life cycle was not shown in the two studies. Chinese scholars have mainly concentrated on the database of embodied energy. With the method of inventory list, Feng [24] compared the LCEU between a flat plate collector and an evacuated tube collector, and Bai [25] calculated the LCEU of solar photovoltaic system by using relevant statistic data. Liu, Wang, Lin, and Peng [26] established an embodied energy database for common building materials and equipment from the data of relevant literature. Gong [27] calculated the LCEU of three residential buildings in Beijing but did not discuss the ZEB and LCZEB.

The above-mentioned studies chiefly focus on the technical measures of NZEB or the LCEU of NZEB. However, realization of LCZEB is unclear and economic analysis is lacking. Thus, in this study, the LCEU of an apartment in the temperate region was calculated on the basis of site survey on household energy use and behavior model, site survey and test on thermal environment, performance simulation of a solar hot water system, and site monitoring of a solar photovoltaic system. Moreover, the technical measures for NZEB and LCZEB were obtained, and net present value (NPV) and PP were used to discuss the economic feasibility of NZEB and LCZEB.

The remainder of the study is organized as follows. Section 3 describes the site survey or test method of building energy use, residents' daily life, and thermal environment. The calculation methods of building energy use, energy yield of solar energy systems, and embodied energy are introduced in the section. Section 4 calculates the indexes of NZEB and LCZEB, namely, NPV, annual net energy (ANE), AEU, annual solar energy (ASE), annual life cycle net energy (ALCNE), annual embodied energy (AEE), and PP. Section 5 summarizes the conclusions.

\section{METHODOLOGY \\ 3.1 Local Climate}

The climate in Kunming is temperate with the distinction of narrow annual temperature range and wide daily temperature range. The average temperature in the coldest month is $8.4{ }^{\circ} \mathrm{C}$ and that in the warmest month is $20.1{ }^{\circ} \mathrm{C}$, which indicates a narrow annual temperature range of $11.7{ }^{\circ} \mathrm{C}$. Meanwhile, the widest daily temperature range is $19.8^{\circ} \mathrm{C}$ with $8.9^{\circ} \mathrm{C}$ as the annual mean of daily temperature range. The annual solar radiation is 5508.9 $\mathrm{MJ} / \mathrm{m}^{2}$, and its distribution is relatively uniform with the minimum of $338.1 \mathrm{MJ} / \mathrm{m}^{2}$ and the maximum of 641.4 $\mathrm{MJ} / \mathrm{m}^{2}$ for monthly solar radiation. Therefore, residential buildings in Kunming do not require air conditioning in summer and heater in winter. The solar hot water and photovoltaic systems can reduce building energy use considerably in Kunming due to the mild climate and rich solar energy.

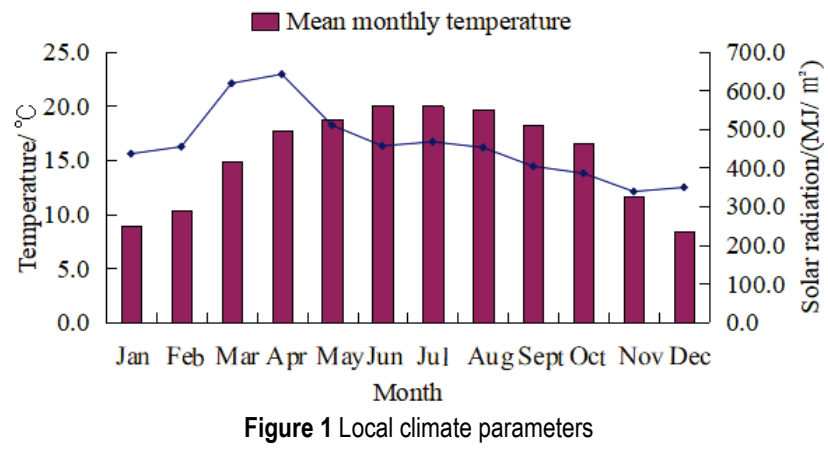

\subsection{Introduction to the Apartment}

Two households are present in each floor in the sixstory apartment, and the floor area of each household is 125 $\mathrm{m}^{2}$. The relevant parameters of the apartment are 0.36 of shape coefficient, $14.03 \%$ of total window-wall ratio, and $18.19 \%$ and $29.43 \%$ of window-wall ratio for the north and the south. Other parameters of the envelope are listed in Tab. 1. No windows are installed on the eastern and western walls. The floor plan and the picture of the apartment are shown in Fig. 2 and 3.

Table 1 Structure and thermal parameters of the envelope of the apartment

\begin{tabular}{|c|c|c|}
\hline Component & Structure & $\begin{array}{c}\text { Heat transfer } \\
\text { coefficient } \\
/\left(\mathrm{W} /\left(\mathrm{m}^{2} \cdot \mathrm{K}\right)\right)\end{array}$ \\
\hline $\begin{array}{c}\text { External and } \\
\text { internal walls }\end{array}$ & $\begin{array}{c}\text { Cement mortar }(20 \mathrm{~mm})+\text { Concrete } \\
\text { hollow block }(200 \mathrm{~mm}) \\
+ \text { Cement mortar }(20 \mathrm{~mm})\end{array}$ & 2.350 \\
\hline $\begin{array}{c}\text { External } \\
\text { window }\end{array}$ & $\begin{array}{c}\text { Aluminum alloy frame with single glass } \\
(6 \mathrm{~mm})\end{array}$ & 6.465 \\
\hline Floor & $\begin{array}{c}\text { Cement mortar }(20 \mathrm{~mm})+\text { Reinforced } \\
\text { concrete }(120 \mathrm{~mm})+\mathrm{Cement} \text { mortar }(20 \\
\mathrm{mm})\end{array}$ & 2.984 \\
\hline Roof & $\begin{array}{c}\text { Asphalt membrane }(4 \mathrm{~mm})+\text { Cement } \\
\text { mortar }(20 \mathrm{~mm})+\text { Reinforced concrete } \\
(120 \mathrm{~mm})\end{array}$ & 3.226 \\
\hline \multicolumn{2}{|c|}{} \\
\hline
\end{tabular}




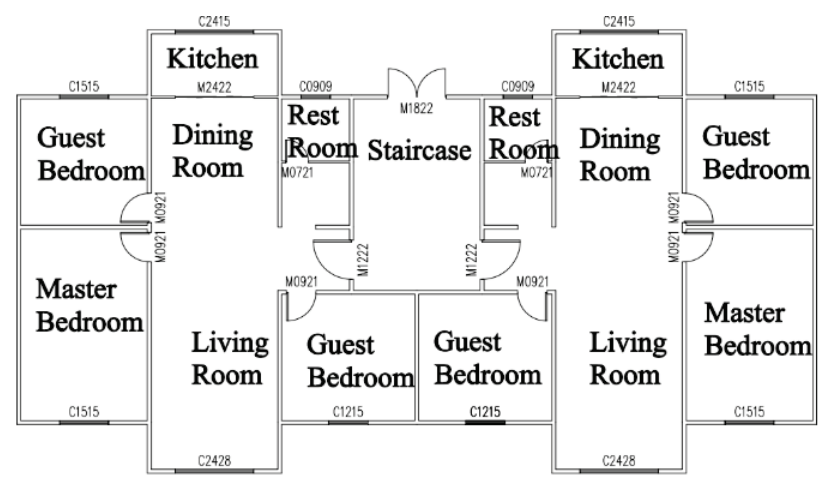

Figure 2 Floor plan of the apartment

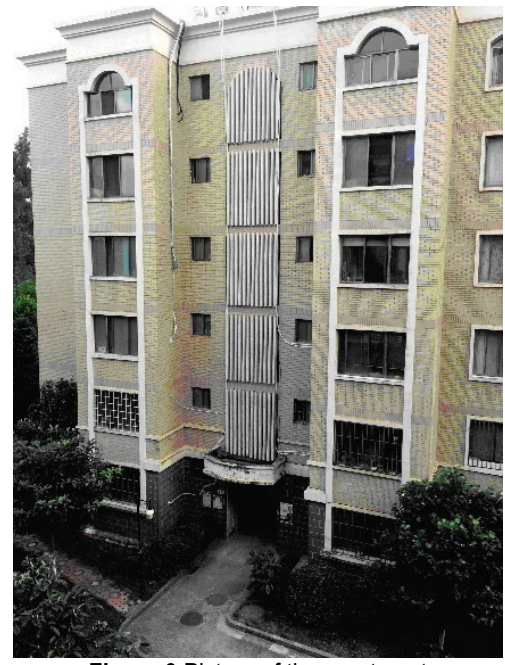

Figure 3 Picture of the apartment

\subsection{Survey on Household Energy Use}

Fifty households in the residential district were used in the survey, which involved household information, energy use and appliances of the households, and behavior model of the residents. In addition, all site surveys and tests in the study were conducted for the entire year of 2017.

\subsection{Site Test of Thermal Environment}

The test in a household was performed from 0:00 to 24:00 once every month in 2017. The test instruments are shown in Tab. 2 and Fig. 4. The testing parameters included indoor and outdoor air temperatures and humidity, wind speeds, air pressures, and wall temperatures of the bedrooms and living room. In addition, the black globe temperature was obtained in the center of the bedrooms and living room. Two solar radiation meters were placed on the southern and western windows, respectively. The test interval was $30 \mathrm{~min}$, and the height for the test was $1.1 \mathrm{~m}$ above the ground. At the same time, four thermographs were placed in the bedrooms and living room, which were set to collect data every $20 \mathrm{~min}$.

The computational formula of hourly mean radiant temperature of some point (cited from Standard of Test Methods for Thermal Environment of Building, JGJ/T 3472014) is

$\bar{t}_{r}=\left[\left(t_{g}+273\right)^{4}+\frac{0.25 \times 10^{8}}{\varepsilon_{g}}\left(\frac{\left|t_{g}-t_{a}\right|}{D}\right)^{1 / 4} \times\left(t_{g}-t_{a}\right)\right]^{1 / 4}-273,(1)$ where, $\bar{t}_{r}$ is the hourly mean radiant temperature of some point $\left({ }^{\circ} \mathrm{C}\right), t_{g}$ is the hourly black globe temperature of some point $\left({ }^{\circ} \mathrm{C}\right), t_{a}$ is the hourly air dry-bulb temperature of some point $\left({ }^{\circ} \mathrm{C}\right), \varepsilon_{g}$ is the emissivity of black globe, and $D$ is the diameter of the black globe $(\mathrm{m})$.

Table 2 Test instruments and testing parameters

\begin{tabular}{|c|c|c|c|}
\hline No. & Test instruments & Type & Testing parameters \\
\hline 1 & $\begin{array}{c}\text { Thermal } \\
\text { anemometer }\end{array}$ & Testo425 & $\begin{array}{c}\text { Indoor and outdoor wind } \\
\text { speeds }\end{array}$ \\
\hline 2 & Thermograph & LR5001-20 & $\begin{array}{c}\text { Indoor and outdoor air } \\
\text { temperatures and humidity }\end{array}$ \\
\hline 3 & $\begin{array}{c}\text { Black bulb } \\
\text { thermometer }\end{array}$ & AZ8778 & $\begin{array}{c}\text { Indoor black globe } \\
\text { temperature }\end{array}$ \\
\hline 5 & $\begin{array}{c}\text { Solar radiation } \\
\text { meter }\end{array}$ & QTS-4 & Outdoor solar radiation \\
\hline 6 & Compound gauge & VC-9200 & $\begin{array}{c}\text { Indoor and outdoor air } \\
\text { pressures }\end{array}$ \\
\hline thermometer & MAXe 62 & Indoor wall temperature \\
\hline
\end{tabular}

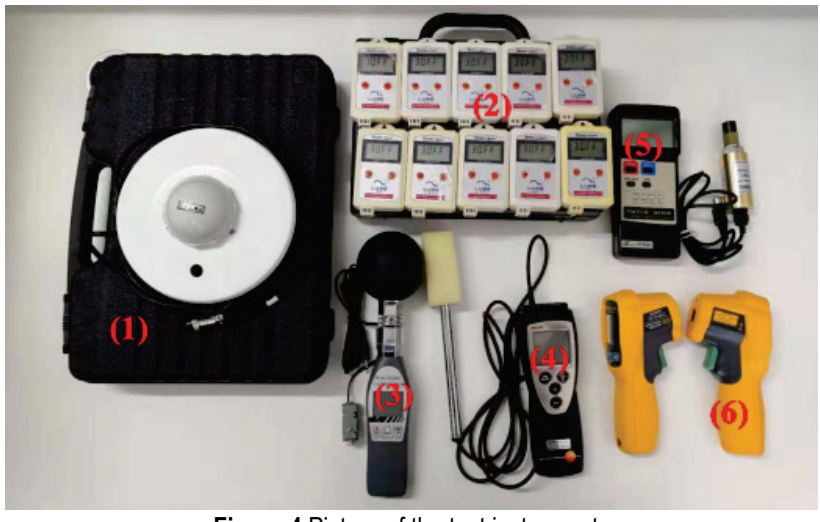

Figure 4 Picture of the test instruments

The computational formula of operative temperature (cited from Evaluation Standard for Indoor Thermal Environment in Civil Buildings, GB/T 50785-2012) is

$t_{o p}=A \cdot t_{a}+(1-A) t_{r}$,

where, $t_{o p}$ is the operative temperature $\left({ }^{\circ} \mathrm{C}\right), t_{a}$ is the air temperature $\left({ }^{\circ} \mathrm{C}\right), t_{r}$ is the mean radiant temperature $\left({ }^{\circ} \mathrm{C}\right)$, and $A$ is 0.5 (air velocity $v<0.2 \mathrm{~m} / \mathrm{s}$ ) or $0.6(0.2 \leq v<0.6)$ or $0.7(0.6 \leq v<1)$.

\subsection{Questionnaire Survey of Thermal Environment}

The questionnaire survey of thermal environment mainly covered gender, age, clothing, activity level, thermal sensation, and indoor comfort. The 25 respondents included 11 males and 14 females with ages between 10 and 80.1.2 met of metabolic rate was adopted because all respondents with suitable clothing were sitting. The thermal sensation value (TSV) was divided into seven levels: $+3=$ hot,$+2=$ warm,$+1=$ slightly warm, $0=$ neutral, $-1=$ slightly cool, $-2=$ cool and $-3=$ cold. The mean of TSV (MTSV) corresponds to the operative temperature because the questionnaire survey and test were simultaneously conducted. 


\subsection{Computation and Simulation of Energy Use}

Energy uses of appliances and cooking equipment were calculated in terms of their power and service time. The calculation formula is

$E C=W \times H \times 365$,

where, $E C$ is the energy use of appliances or cooking equipment, $W$ is the power of appliances or cooking equipment $(\mathrm{kW})$, and $H$ is the daily service time of appliances or cooking equipment $(\mathrm{h})$.

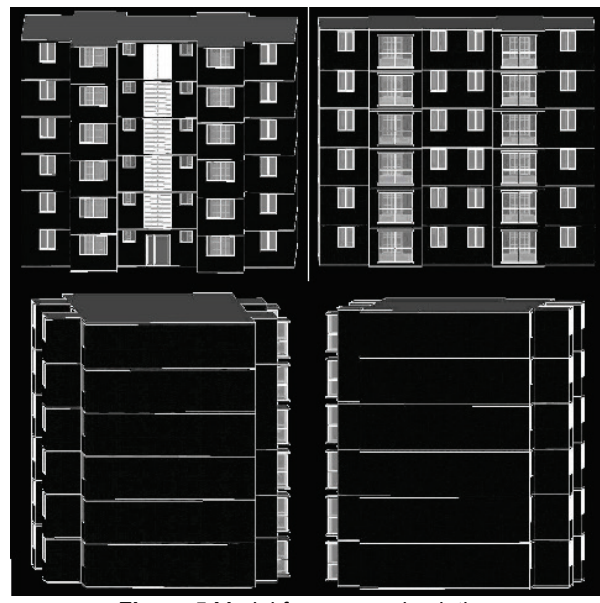

Figure 5 Model for energy simulation

Table 3 Structure and thermal parameters of the envelope of the energy simulation model

\begin{tabular}{|c|c|c|}
\hline Component & Structure & $\begin{array}{l}\text { Heat transfer } \\
\text { coefficient } \\
/\left(\mathrm{W} /\left(\mathrm{m}^{2} \cdot \mathrm{K}\right)\right)\end{array}$ \\
\hline $\begin{array}{l}\text { External and } \\
\text { internal walls }\end{array}$ & $\begin{array}{c}\text { Thermal insulation mortar }(20 \mathrm{~mm}) \\
+ \text { Hollow block of light aggregate } \\
\text { concrete }(250 \mathrm{~mm}) \\
+ \text { Cement mortar }(20 \mathrm{~mm}) \\
\end{array}$ & 1.562 \\
\hline $\begin{array}{l}\text { External } \\
\text { window }\end{array}$ & $\begin{array}{l}\text { Heat insulation aluminum alloy frame } \\
\text { with double glazing } \\
\text { (glass } 6 \mathrm{~mm}+\text { air } 12 \mathrm{~mm}+ \\
\text { glass } 6 \mathrm{~mm})\end{array}$ & 3.24 \\
\hline Floor & $\begin{array}{c}\text { Cement mortar }(20 \mathrm{~mm})+\text { Reinforced } \\
\text { concrete }(120 \mathrm{~mm})+\text { Cement mortar }(20 \\
\mathrm{mm})\end{array}$ & 2.984 \\
\hline Internal wall & $\begin{array}{c}\text { Cement mortar }(20 \mathrm{~mm})+ \\
\text { Hollow block of light aggregate } \\
\text { concrete }(110 \mathrm{~mm}) \\
+ \text { Cement mortar }(20 \mathrm{~mm})\end{array}$ & 2.54 \\
\hline Roof & $\begin{array}{c}\text { Concrete }(20 \mathrm{~mm})+ \\
\text { EPS }(15 \mathrm{~mm})+ \\
\text { Asphalt membrane }(4 \mathrm{~mm})+\text { Cement } \\
\text { mortar }(20 \mathrm{~mm})+\text { Concrete }(200 \mathrm{~mm})\end{array}$ & 1.431 \\
\hline
\end{tabular}

Energy use of domestic hot water was calculated from hot water consumption and the chosen heat-pump water heater. Forty liters were considered daily hot water consumption per person (cited from Standard FOR Water Saving Design IN Civil Building, GB50555-2010), and the cool water temperature could be referred to surface water temperature. In addition, each household was assumed to contain three persons. Then, the daily thermal loads of hot water per household could be calculated as follows:

$Q=V_{s} \times C_{p} \times\left(T_{w}-T_{c}\right)$, where, $V_{s}$ is the hot water consumption per household $(\mathrm{kg})$, $C_{p}$ is the specific heat of water at constant pressure (4.187 $\left.\mathrm{kJ} /\left(\mathrm{kg} \cdot{ }^{\circ} \mathrm{C}\right)\right), T_{w}$ is the hot water temperature $\left(60{ }^{\circ} \mathrm{C}\right)$, and $T_{c}$ is the cold water temperature $\left(10^{\circ} \mathrm{C}\right.$ in winter and $15^{\circ} \mathrm{C}$ in other seasons)

Energy use for heating and lighting was simulated in DesignBuilder. The simulation model (Fig. 5) was established on the basis of the shop drawing and behavior model of the residents. Simulation parameters were set as follows: indoor activities were set in accordance with the survey data, thermal performance of envelope met the requirements of local building energy codes (Tab. 3), air conditioning was unused, the COP of heat pump for heating was 3.6, and indoor illumination was set in accordance with Standard for Lighting Design of Buildings, GB50034-2013.

\subsection{Principle for the Selection of Energy-saving Measures}

Poortinga, Steg, and Vlek [28] divided energy-saving measures into two types: high quality equipment / material and behavioral energy saving. The former requires to purchase a large number of efficient products, which costs high at the beginning, but energy expenses can drop later. In the second condition, it costs less or none, but residents have to change their behavior consciously. This condition will lower the quality of life. Therefore, in the study, highefficient equipment and high-performance materials were used to maximize the profits. In particular, the lowest quality equipment or material which still meets the mandatory regulations was set as a reference, and the relative NPVs of other equipment and material were computed. The equipment or material with maximum NPV was the final option. The local electricity price was $\$ 0.0726 / \mathrm{kWh}$, and the calculation period was determined to be 20 years considering the service life of equipment and appliances. The computational formula is

$N P V_{i}=\Delta E_{i}\left(P / A, i_{0}, n\right)-\Delta C_{i}$,

where, $N P V_{i}$ is the relative $N P V$ of the $i^{\text {th }}$ type of equipment or material (\$), $\Delta E_{i}$ is the annual saved energy expenses of the $i^{\text {th }}$ type of equipment or material compared with the reference $(\$), i_{0}$ is the discount rate $(4.35 \%), n$ is the calculation period (20 years), and $\Delta C_{i}$ is the incremental purchase cost of the $i^{\text {th }}$ type of equipment or material compared with the reference (\$).

\subsection{Solar Energy Systems}

A NZEB is a building whose energy needs can be offset by renewable technologies [29]. A solar hot water system and a virtual solar photovoltaic system were also used to realize NZEB and LCZEB in the study.

A centralized system of solar hot water with a heat pump as auxiliary thermal source (Fig. 6) supplied hot water. Fifteen thermal collectors of flat plate were installed on the roof, and the area of each collector was $2 \mathrm{~m}^{2}$. A solar photovoltaic system was utilized in the apartment to realize zero energy. In terms of available space, 78 photovoltaic panels could be installed on the roof. Relevant parameters of each panel were expressed as follows: the width was 
$0.98 \mathrm{~m}$, the length was $1.65 \mathrm{~m}$, and the power was $250 \mathrm{~W}_{\mathrm{p}}$. Then, the total area of the panels was $126 \mathrm{~m}^{2}$, and the total power was $19.5 \mathrm{~kW}_{\mathrm{p}}$. The eventual roof plan for the solar energy systems is shown in Fig. 7.

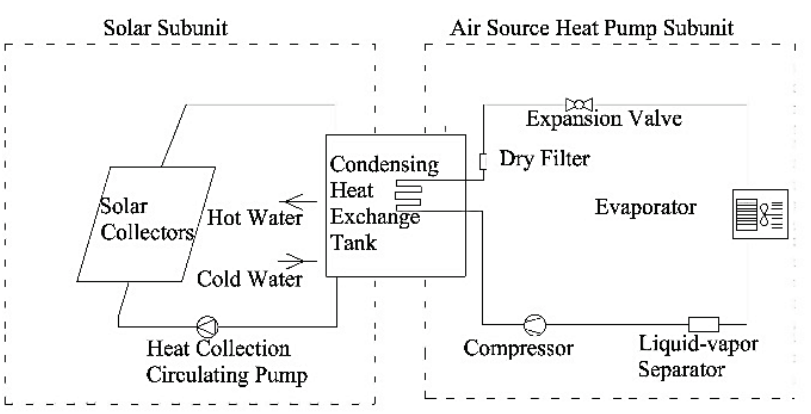

Figure 6 System schematic of the solar hot water system

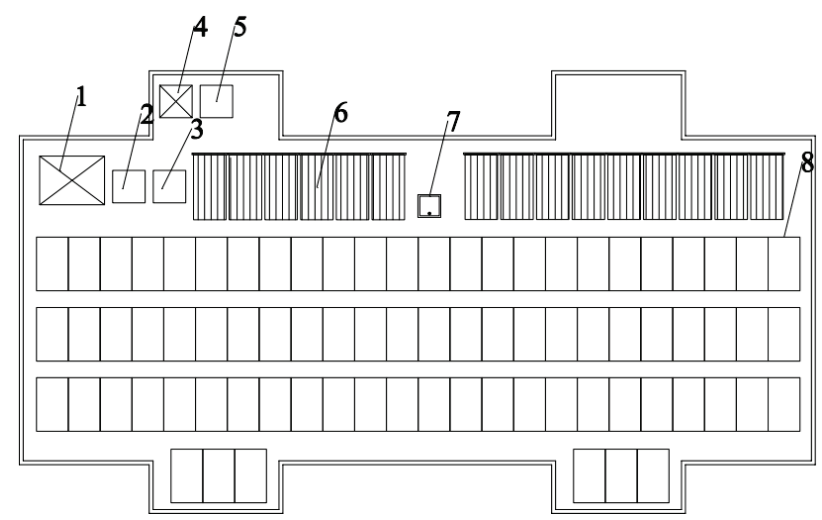

Figure 7 Roof plan for thermal collectors and photovoltaic panels: 1 - Electrical Cabinet, 2 - Solar Inverter, 3 - Photovoltaic Controller, 4 - Water tank, 5 - Heat Pump, 6 - Thermal Collector, 7 - Roof Access, 8 - Photovoltaic Panel

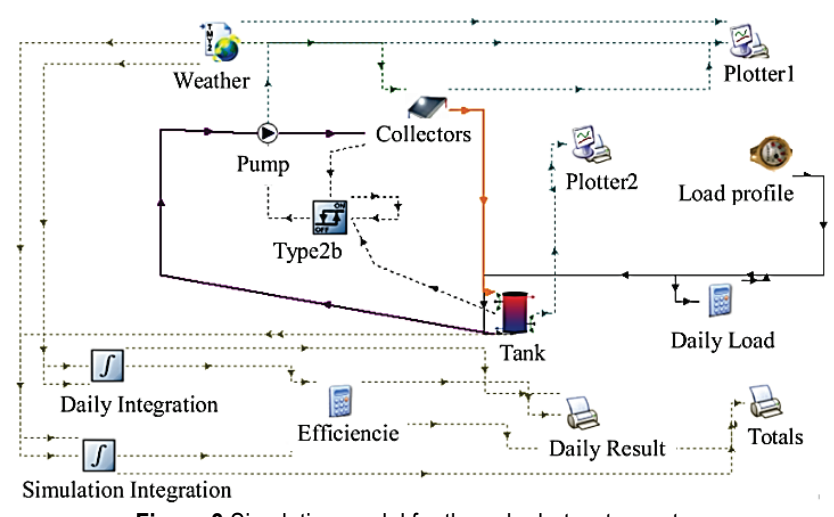

Figure 8 Simulation model for the solar hot water system

Table 4 Parameter of the simulation model for the solar hot water system

\begin{tabular}{|c|c|c|}
\hline Component & Parameter & Value \\
\hline \multirow{3}{*}{$\begin{array}{c}\text { Thermal } \\
\text { collector }\end{array}$} & Area & $30 \mathrm{~m}^{2}$ \\
\cline { 2 - 3 } & Heat-gain efficiency & 0.50 \\
\cline { 2 - 3 } & Angle of tilt & $30^{\circ}$ \\
\cline { 2 - 3 } & Azimuth angle & South \\
\hline \multirow{4}{*}{ Water tank } & Capacity & $1800 \mathrm{~L}$ \\
\cline { 2 - 3 } & Heat-loss factor & $0.2 \mathrm{~W} /\left(\mathrm{m}^{2 \cdot}{ }^{\circ} \mathrm{C}\right)$ \\
\cline { 2 - 3 } & Height & $2 \mathrm{~m}$ \\
\cline { 2 - 3 } Water pump & Thermal stratification & Four layers \\
\hline \multirow{4}{*}{ Controller } & Flow rate & $1.2 \mathrm{t} / \mathrm{h}$ \\
\cline { 2 - 3 } & Circulating water pump & ON/OFF \\
\cline { 2 - 3 } & Air source heat pump & Operate if $T<55^{\circ} \mathrm{C}$ \\
& Stop if $T \geq 60^{\circ} \mathrm{C}$ \\
\cline { 2 - 3 } & Anti-overheating & Stop if $T>80^{\circ} \mathrm{C}$ \\
\hline
\end{tabular}

The hot water production of the solar hot water system was simulated in TRNSYS (the simulation model is shown in Fig. 8, and the designed parameters are shown in Tab. 4).

The power generation of the virtual solar photovoltaic system was calculated on the basis of an operating system. The operating solar photovoltaic system (Fig. 9 and 10) was placed on the roof of a dormitory in Kunming. The area of 294 photovoltaic panels was $476 \mathrm{~m}^{2}$, and the total power was $73.5 \mathrm{~kW}_{\mathrm{p}}$. A monitoring system was used to automatically record the power generation every $10 \mathrm{~min}$.

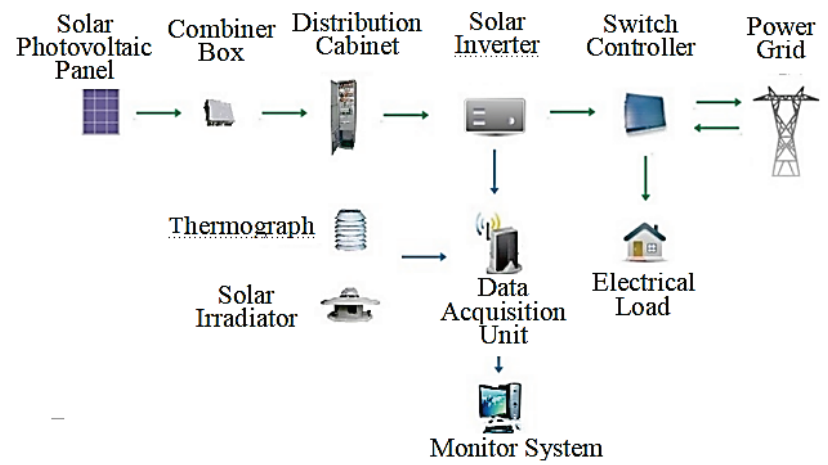

Figure 9 System schematic of the operating solar photovoltaic system

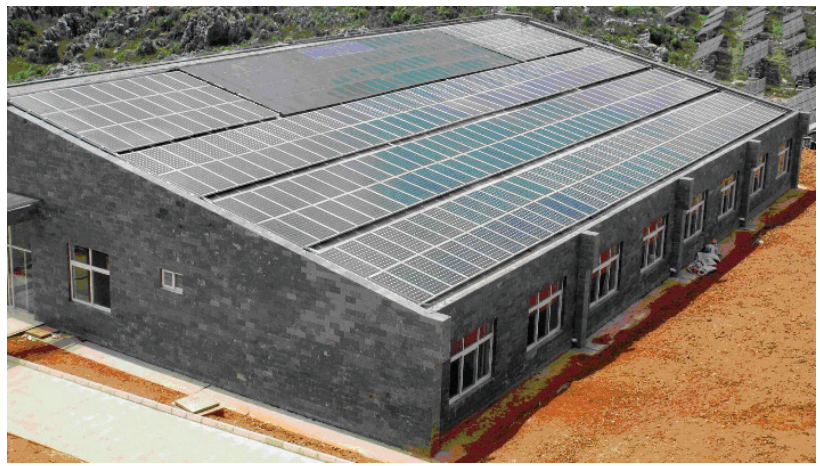

Figure 10 Picture of the operating solar photovoltaic system

\subsection{Calculation of Embodied Energy}

Embodied energy included energy use of manufacturing, installation, maintenance, and demolition of materials and equipment. The calculation of embodied energy included walls, windows, floors, roofs, appliances, cooking and lighting equipment, and solar hot water and photovoltaic systems, except for furnishings and general plumbing. The basic data of embodied energy were expressed as follows: $1179.35 \mathrm{kWh} / \mathrm{m}^{2}$ for buildings, $1243.56 \mathrm{kWh}$ for a refrigerator, $2360.89 \mathrm{kWh}$ for a TV, $1634.14 \mathrm{kWh}$ for a washing machine, $1928.27 \mathrm{kWh}$ for a computer, $408 \mathrm{kWh}$ for an electrical cooker, $903.18 \mathrm{kWh}$ for a heat pump, $301.33 \mathrm{kWh}$ for a microwave oven, 401.42 $\mathrm{kWh}$ for a kitchen ventilator, $538.67 \mathrm{kWh}$ for a gas stove, $1644 \mathrm{kWh} / \mathrm{m}^{2}$ for LED, $1737.96 \mathrm{kWh} / \mathrm{m}^{2}$ for thermal collector, and $1362.47 \mathrm{kWh} / \mathrm{m}^{2}$ for photovoltaic panel [2427].

\subsection{Energy Balance of NZEB and LCZEB} NZEB is

The computational formula for energy balance of $A N E=A E U-A S E$, 
where, $A N E$ is the ANE $(\mathrm{kWh}) ; A E U$ is the AEU $(\mathrm{kWh})$, which includes the energy use of appliances (AEU1), the energy use for cooking ( $A E U 2)$, the energy use for hot water (AEU3), the energy use for heating (AEU4), and the energy use for lighting ( $A E U 5) ; A S E$ is the annual output of solar energy $(\mathrm{kWh})$, which includes the annual energy yield of the solar hot water system $(A S E 1)$ and the solar photovoltaic system (ASE2).

In line with the calculation of NPV, the calculation period of LCZEB was 20 years. The computational formula for energy balance of LCZEB is

$$
A L C N E=A N E+A E E,
$$

where, $A L C N E$ is the ALCNE (kWh) and $A E E$ is the AEE $(\mathrm{kWh})$.

Table 5 Statistical analysis on the survey data of household energy use

\begin{tabular}{|c|c|c|c|c|}
\hline Index & $\begin{array}{c}\text { Mean } \\
\text { value }\end{array}$ & $\begin{array}{c}\text { Standard } \\
\text { deviation }\end{array}$ & $\begin{array}{c}\text { Skewness } \\
\text { coefficient }\end{array}$ & $\begin{array}{c}\text { Kurtosis } \\
\text { coefficient }\end{array}$ \\
\hline AEU $/ \mathrm{kWh}$ & 3451.07 & 933.04 & 0.63 & -0.26 \\
\hline $\begin{array}{c}\mathrm{AEU} \text { per floor } \\
\text { area } \\
\left./ \mathrm{kWh} /\left(\mathrm{m}^{2} \cdot \mathrm{a}\right)\right)\end{array}$ & 27.80 & 2.21 & -0.30 & 1.10 \\
\hline
\end{tabular}

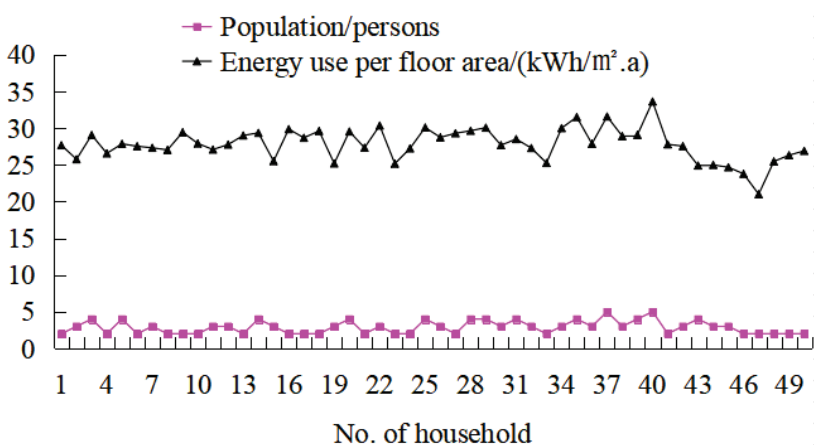

Figure 11 Population and energy use of sample households

Table 6 Service time of appliances and cooking equipment

\begin{tabular}{|c|c|c|c|c|}
\hline \multirow{2}{*}{ Equipment } & Parameter & \multirow{2}{*}{ Value } & \multicolumn{2}{|c|}{$\begin{array}{c}\text { Service time } \\
\text { every day/h }\end{array}$} \\
\cline { 4 - 5 } & & & Work-days & $\begin{array}{c}\text { Non } \\
\text { workdays }\end{array}$ \\
\hline Refrigerator & Volume & $220 \mathrm{~L}$ & 24 & 24 \\
\hline $\mathrm{TV}$ & $\begin{array}{c}\text { Diagonal } \\
\text { length }\end{array}$ & 55 inch & 4 & 8 \\
\hline $\begin{array}{c}\text { Washing } \\
\text { machine }\end{array}$ & Weight & $6 \mathrm{~kg}$ & 0 & 1 \\
\hline $\begin{array}{c}\text { Computer } \\
\text { Electric } \\
\text { cooker }\end{array}$ & $\begin{array}{c}\text { Diagonal } \\
\text { length }\end{array}$ & $20 \mathrm{inch}$ & 4 & 8 \\
\hline $\begin{array}{c}\text { Microwave } \\
\text { oven }\end{array}$ & Volume & $4 \mathrm{~L}$ & 0.7 & 1.4 \\
\hline Ventilator & Volume & $20 \mathrm{~L}$ & 0.25 & 0.50 \\
\hline Gas stove & Heat & $4000 \mathrm{~W}$ & 0.5 & 1 \\
\hline
\end{tabular}

Table 7 Possible duration of residents' stay in different room

\begin{tabular}{|c|c|c|}
\hline Type of room & Workdays & Non workdays \\
\hline Bedroom & $23: 00-8: 00$ & $23: 00-8: 00$ \\
\hline Living room & $18: 00-23: 00$ & $8: 00-23: 00$ \\
\hline \multirow{2}{*}{ Dining room \& Kitchen } & $6: 00-7: 00$, & $7: 00-8: 00$, \\
& $18: 00-20: 00$ & $11: 00-13: 00$, \\
& $6: 00-20: 00$ \\
\hline \multirow{2}{*}{ Bathroom } & $6: 00-8: 00$, & $7: 00-23: 00$ \\
\hline
\end{tabular}

\section{RESULT ANALYSIS AND DISCUSSION}

\subsection{Summary of the Survey on Household Energy Use}

The results of statistical analysis on the survey data of household energy use in 2017 are shown in Tab. 5, and the population and energy use per floor area for the households are shown in Fig. 11. The service times of common appliances (e.g., refrigerator, TV, washing machine, and computer) and cooking equipment (e.g., electric cooker, microwave oven, ventilator, and gas stove) are provided in Tab. 6 . The survey demonstrates that no air conditioning is available in all households, but electric heater is found in each household. The nuclear family accounts for the largest proportion. Thus, its behavior model was used for energy simulation (Tab. 7).

\subsection{Thermal Comfort}

On the basis of site test data, the operative temperature was calculated using Eq. (1) and (2) (Fig. 12). In winter, electric heater is used only in the living room before sleeping. Meanwhile, the survey data reveal that the range of clothing insulation in winter is from 0.54 clo to 2.88 clo and that in other times is from 0.15 clo to 1.65 clo, which indicates that the residents used to change clothes to adapt to climate changes in other seasons. The acceptable operative temperature range for naturally conditioned spaces will be suitable for the evaluation of indoor thermal comfort. The range will be from $16{ }^{\circ} \mathrm{C}$ to $30{ }^{\circ} \mathrm{C}$ based on Evaluation Standard for Indoor Thermal Environment in Civil Buildings, GB/T 50785-2012.

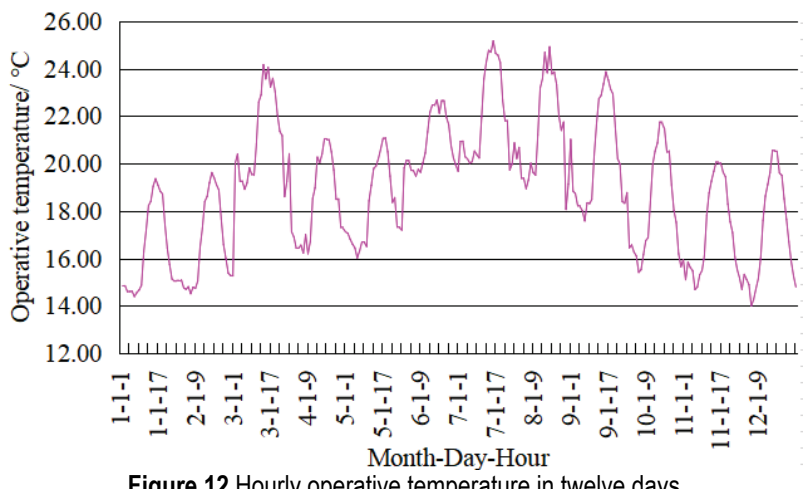

Figure 12 Hourly operative temperature in twelve days

Fig. 12 shows that the residents may require heating in January, February, November, and December and do not require heating or cooling in the rest of the year, which agrees with site survey. The regression equation $M T S V=$ $0.4817 t_{o p}-7.536\left(R^{2}=0.9547\right)$ can be obtained on the basis of the above-mentioned operative temperature and MTS from questionnaire survey in winter. The neutral temperature can be $15.6{ }^{\circ} \mathrm{C}$ when $M T S V=0$, which was used as the indoor design operative temperature for heating energy simulation.

\subsection{Optimal Energy Use for Appliances and Cooking Equipment}

The appliances and cooking equipment with lowest energy efficiency were used as the benchmark, and those NPVs with high energy efficiency were calculated using Eq. (5). Then, appliances and cooking equipment with the 
maximum NPV were used (Tab. 8). The survey reflects that appliances may not be used simultaneously and that residents will go out for dinner occasionally. Thus, a simultaneous coefficient (0.8) was used. Energy use of appliances and cooking equipment was calculated using Eq. (3) and Tab. 6. The AEU of appliances for each household is $616.18 \mathrm{kWh}$ and that for the apartment is $7394.11 \mathrm{kWh}$. The AEU of cooking equipment for each household is $408.89 \mathrm{kWh}$ and that for the entire apartment is $4906.68 \mathrm{kWh}$.

Table 8 Selection of appliances and cooking equipment

\begin{tabular}{|c|c|c|c|c|}
\hline Equipment & $\begin{array}{c}\text { Energy } \\
\text { efficiency grade }\end{array}$ & $\begin{array}{c}\text { Purchase } \\
\text { cost } / \$\end{array}$ & $A E U / \mathrm{kWh}$ & $N P V / \$$ \\
\hline \multirow{3}{*}{ Refrigerator } & 3 & 225.67 & 124.1 & 0 \\
\hline & 2 & 204.08 & 113.15 & 30.89 \\
\hline & 1 & 284.76 & 98.6 & -36.82 \\
\hline \multirow{3}{*}{ TV } & 3 & 484.32 & 224.43 & 0 \\
\hline & 2 & 583.37 & 198.77 & -76.49 \\
\hline & 1 & 619.84 & 166.25 & -84.76 \\
\hline \multirow{3}{*}{$\begin{array}{l}\text { Washing } \\
\text { machine }\end{array}$} & 3 & 145.59 & 95.68 & 0 \\
\hline & 2 & 291.47 & 64.48 & -118.34 \\
\hline & 1 & 252.95 & 67.5 & -78.19 \\
\hline \multirow{3}{*}{ Computer } & 1 & 452.08 & 336.96 & 0 \\
\hline & 1 & 507.66 & 336.96 & -55.34 \\
\hline & 1 & 684.90 & 336.96 & -231.81 \\
\hline \multirow{3}{*}{$\begin{array}{l}\text { Electric } \\
\text { cooker }\end{array}$} & 3 & 31.95 & 128.6 & 0 \\
\hline & 2 & 66.96 & 120.9 & 0.90 \\
\hline & 1 & 87.38 & 112.7 & -41.39 \\
\hline \multirow{3}{*}{$\begin{array}{c}\text { Microwave } \\
\text { oven }\end{array}$} & 3 & 50.91 & 29.3 & 0 \\
\hline & 2 & 64.04 & 28.2 & -13.57 \\
\hline & 1 & 66.37 & 31.2 & -17.12 \\
\hline \multirow{3}{*}{ Ventilator } & 3 & 164.70 & 47.45 & 0 \\
\hline & 2 & 190.66 & 40.15 & -19.53 \\
\hline & 1 & 198.40 & 33.76 & -21.75 \\
\hline \multirow{2}{*}{ Gas stove } & 2 & 88.40 & $85.88 \mathrm{~m}^{3}$ & 0 \\
\hline & 1 & 160.32 & $79.44 \mathrm{~m}^{3}$ & -30.78 \\
\hline
\end{tabular}

Note: The conversion factor of natural gas is $3.65 \mathrm{kWh} / \mathrm{m}^{3}$ in accordance with General Principles for Calculation of Comprehensive Energy Consumption, GB/T 2589-2008.

Table 9 NPVs of heating schemes with different thickness of EPS plates

\begin{tabular}{|c|c|c|c|c|}
\hline Thickness $/ \mathrm{mm}$ & $A E U / \mathrm{kWh}$ & $\Delta C / \$$ & $\Delta E / \$$ & $N P V / \$$ \\
\hline 0 & 3586.62 & 0 & 0 & 0 \\
\hline 10 & 3248.82 & 3180.5 & 24.5 & -2857.2 \\
\hline 15 & 3136.8 & 4593.4 & 32.7 & -4162.9 \\
\hline 20 & 3053.82 & 6808.3 & 38.7 & -6298.3 \\
\hline 25 & 2982.48 & 9178.6 & 43.9 & -8600.4 \\
\hline 30 & 2923.02 & 10228.8 & 48.2 & -9593.7 \\
\hline 35 & 2872.02 & 11952.6 & 51.9 & -11268.7 \\
\hline 40 & 2826.06 & 13613.8 & 55.2 & -12885.9 \\
\hline 45 & 2778 & 15144.0 & 58.7 & -14370.1 \\
\hline 50 & 2741.64 & 17020.7 & 61.4 & -16212.0 \\
\hline 55 & 2707.98 & 17266.1 & 63.8 & -16425.2 \\
\hline 60 & 2676.9 & 17675.3 & 66.1 & -16804.6 \\
\hline 65 & 2647.68 & 18111.7 & 68.2 & -17213.1 \\
\hline
\end{tabular}

\subsection{Optimal Energy Use for Hot Water}

The daily hot water load per household in winter is calculated to be $25.12 \mathrm{MJ}$ using Eq. (4), which is $22.61 \mathrm{MJ}$ in other seasons. Therefore, the total hot water loads of the apartment are 107254.56 MJ. The COP of the heat-pump water heater is 3.6. The thermal loss rate of the water tank and pipeline is set to $0.3 \%$. Then, the AEU for hot water of the entire apartment is $29882.58 \mathrm{kWh}$. The survey indicates that a resident will normally take a bath once every three days in winter and once a day and a half in other seasons. On this condition, the final energy use is discounted to $24902.15 \mathrm{kWh}$.

\subsection{Optimal Energy Use for Heating}

The thermal performance of the envelope is a key factor to reduce the energy use for heating. Thus, the envelope shown in Tab. 3 was considered the baseline, and the addition of EPS plates on outside walls was the alternative. Then, the energy use for heating was simulated in DesignBuilder. Subsequently, the NPV for different schemes was calculated using Eq. (5) (Tab. 9). The envelope without EPS plates was the optimal choice. In this case, the AEU for heating is $3586.62 \mathrm{kWh}$.

\subsection{Optimal Energy Use for Lighting}

Different LED sources were used as alternative schemes to meet the requirements of illuminance and lighting power density (LPD). Energy use for lighting was simulated in DesignBuilder. Lighting scheme with the maximum NPV was selected on the basis of the NPVs calculated using Eq. (5) (Tab. 10). Under this circumstance, the AEU for lighting is $5985.42 \mathrm{kWh}$.

Table 10 NPVs of different lighting schemes

\begin{tabular}{|c|c|c|c|c|c|}
\hline $\begin{array}{c}\text { Luminous } \\
\text { flux } / \mathrm{lm}\end{array}$ & $\begin{array}{c}L P D \\
/\left(\mathrm{W} / \mathrm{m}^{2}\right)\end{array}$ & $\begin{array}{c}A E U \\
/ \mathrm{kWh}\end{array}$ & $\Delta C / \$$ & $\Delta E / \$$ & $N P V / \$$ \\
\hline 650 & 6 & 10494.3 & 0 & 0 & 0 \\
\hline 650 & 5.8 & 10147.4 & 384.3 & 25.2 & -52.3 \\
\hline 800 & 5.6 & 9800.58 & 303.3 & 50.4 & 360.7 \\
\hline 850 & 5.4 & 9453.78 & 366.0 & 75.6 & 629.8 \\
\hline 900 & 5.2 & 9106.74 & 598.7 & 100.8 & 729.3 \\
\hline 950 & 5 & 8759.94 & 800.0 & 126.0 & 859.9 \\
\hline 1000 & 4.8 & 8413.26 & 1082.4 & 151.1 & 909.3 \\
\hline 1050 & 4.6 & 8066.46 & 1427.5 & 176.3 & 896.1 \\
\hline 1050 & 4.4 & 7719.54 & 1218.3 & 201.5 & 1437.3 \\
\hline 1150 & 4.2 & 7372.86 & 1406.5 & 226.7 & 1580.9 \\
\hline 1200 & 4 & 7026.06 & 1647.1 & 251.9 & 1672.2 \\
\hline 1300 & 3.8 & 6679.14 & 1657.5 & 277.1 & 1993.8 \\
\hline 1450 & 3.6 & 6332.46 & 2065.4 & 302.2 & 1917.8 \\
\hline 1600 & 3.4 & 5985.42 & 1992.2 & 327.4 & 2323.1 \\
\hline 1800 & 3.2 & 5638.62 & 2941.2 & 352.6 & 1706.0 \\
\hline 1850 & 3 & 5291.94 & 3539.9 & 377.8 & 1439.1 \\
\hline
\end{tabular}

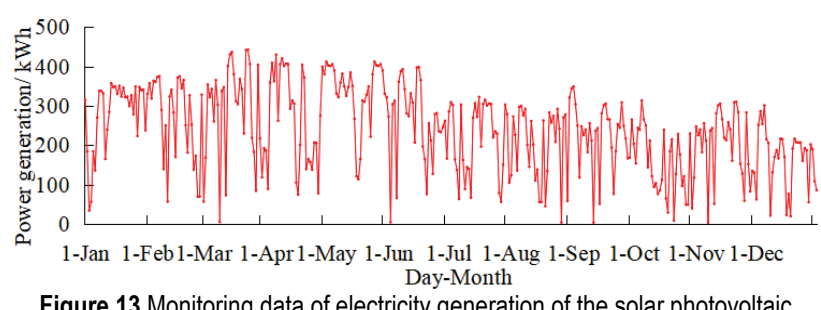

Figure 13 Monitoring data of electricity generation of the solar photovoltaic system in one year

\subsection{Annual Energy Yield of Solar Energy Systems}

The simulation in TRNSYS demonstrates that the annual heat gain of the solar hot water system is $71064.81 \mathrm{MJ}$, which is equal to $19740.23 \mathrm{kWh}$ with the heat-pump water heater as the reference. The annual power generation is $87263.51 \mathrm{kWh}$ based on the monitoring data of the operating solar photovoltaic system in 2017 (Fig. 13). Therefore, the power generation of the virtual solar photovoltaic system is predicted to be $23151.6 \mathrm{kWh}$ for the year. The NPV of thermal collector per square meter is $\$ 455.5$, and the NPV of the photovoltaic panel per square meter is $\$ 13.2$ based on the results calculated using Eq. (5). 


\subsection{Annual Embodied Energy}

AEE for the building and equipment calculated from the basic data in Section 3.9 is expressed as follows: the AEE of the building is $35380.38 \mathrm{kWh}$, the AEE of appliances (including heat pump) is $4932.34 \mathrm{kWh}$, the AEE of cooking equipment is $989.65 \mathrm{kWh}$, the AEE of lighting equipment is $986.40 \mathrm{kWh}$, the AEE of solar hot water system is $2606.94 \mathrm{kWh}$, and the AEE of solar photovoltaic system is $8583.59 \mathrm{kWh}$. In addition, the ANE of thermal collector per square meter is $-571.11 \mathrm{kWh}$, and the ANE of photovoltaic panel per square meter is $-115.62 \mathrm{kWh}$.

\subsection{Analysis of NZEB}

On the basis of the above-mentioned results (i.e., $7394.11 \mathrm{kWh}$ of AEU1, $4906.68 \mathrm{kWh}$ of AEU2, 24902.15 $\mathrm{kWh}$ of AEU3, $3586.62 \mathrm{kWh}$ of AEU4, 5985.42 kWh of AEU5, $19740.23 \mathrm{kWh}$ of ASE1, and $23151.6 \mathrm{kWh}$ of ASE2), the ANE calculated using Eq. (6) is 3883.15 $\mathrm{kWh} / \mathrm{a}$, which indicates the failure of NZEB. Here, the floor area of the apartment should be decreased to reduce the AEU. Under such circumstances, considerable spaces are available for the solar photovoltaic system if $2.5 \mathrm{~m}^{2}$ of thermal collector per household remain unchanged. Accordingly, the area of thermal collectors drops to $25 \mathrm{~m}^{2}$, and that of photovoltaic panels rises to $131 \mathrm{~m}^{2}$ when the story decreases to 5. Consequently, the ANE reduces to $-1541.35 \mathrm{kWh}$, which means the five-story apartment can realize the NZEB. At the same time, the NPV is $\$ 15369.64$, and the PP is 11 years.

\subsection{Analysis of LCZEB}

The AEE is $48327.36 \mathrm{kWh}$ and the ANE is -1541.35 $\mathrm{kWh}$ when the story decreases to 5. Therefore, the ALCNE calculated using Eq. (7) is $46786.00 \mathrm{kWh}$. The ANEs are $-6965.86,-12390.37,-17814.87$, and $-23239.38 \mathrm{kWh}$ when the story decreases to $4,3,2$, and 1 , respectively. Meanwhile, the AEEs are 41373.10, 34418.84, 27464.58, and $20510.32 \mathrm{kWh}$, and the ALCNEs are 34407.24, $22028.47,9649.71$, and $-2729.06 \mathrm{kWh}$. Therefore, a onestory apartment can realize the LCZEB. The NPV and PP of the one-story apartment are $\$ 4718.77$ and 16 years, respectively.

\begin{tabular}{|} 
Table 11 LCZEB for the other four climatic regions \\
\begin{tabular}{|c|c|c|c|c|}
\hline & $M T K$ & $B J$ & $C S$ & $G Z$ \\
\hline $\begin{array}{c}\text { Solar } \\
\text { radiation } \\
/\left(\mathrm{MJ} / \mathrm{m}^{2}\right)\end{array}$ & 4585.3 & 5042.1 & 3902.5 & 4086.6 \\
\hline $\begin{array}{c}\text { Thermal } \\
\text { collectors } / \mathrm{m}^{2}\end{array}$ & 5 & 5 & 5 & 5 \\
\hline $\begin{array}{c}\text { Photovoltaic } \\
\text { panels } / \mathrm{m}^{2}\end{array}$ & 306 & 257 & 425 & 385 \\
\hline$A E U / \mathrm{kWh}$ & 21200.5 & 21200.5 & 21200.5 & 21200.5 \\
\hline$A S E / \mathrm{kWh}$ & 49537.2 & 46231.8 & 57650.1 & 54917.5 \\
\hline$A N E / \mathrm{kWh}$ & -28336.7 & -25031.3 & -36449.6 & -33717.0 \\
\hline$A E E / \mathrm{kWh}$ & 28328.5 & 24990.4 & 36435.2 & 33710.2 \\
\hline$A L C N E / \mathrm{kWh}$ & -8.2 & -40.9 & -14.4 & -6.8 \\
\hline
\end{tabular}
\end{tabular}

Guidelines for Passive Low-Energy Green Building issued by Ministry of Housing and Urban-rural Development of the P. R. C. stipulates the energy use for heating, cooling and lighting should be less than $60 \mathrm{kWh} /$ $\left(\mathrm{m}^{2} \cdot \mathrm{a}\right)$. Then, if Mutankiang (MTK), Beijing (BJ), Changsha (CS), Guangzhou (GZ) are chosen as the typical cities for severe cold region, cold region, hot summer and cold winter region, and hot summer and warm winter region respectively, the final results (Tab. 11) show that more photovoltaic panels can realize LCZEB for the other four climatic regions considering the differences of the climate and solar radiation.

\section{CONCLUSIONS}

A multi-story apartment in the mild region was used as the research object to discuss the feasibility of NZEB and LCZEB. NZEB and LCZEB were realized by applying energy-saving measures, such as utilizing high-efficient building equipment, high-performance materials, and solar energies. The following conclusions could be drawn:

(1) The five-story apartment can realize NZEB and the one-story apartment can realize LCZEB when solar energy systems are placed on the roof. The one-floor apartment in other climatic regions can realize LCZEB by increasing the power of solar photovoltaic system.

(2) Full utilization of solar energy is the key energysaving measure to realize NZEB and LCZEB. The energy yield and economical efficiency of thermal collector per square meter are higher than those of solar photovoltaic panel per square meter.

(3) NZEB and LCZEB have higher economic benefits than buildings that meet local building energy codes.

(4) The economic benefits of NZEB are higher than those of LCZEB in terms of PP.

In this study, LCEU of a multi-story apartment in Kunming was analyzed on the basis of survey, site test, monitoring, and simulation data. The analysis results prove the economic feasibility of NZEB and LCZEB. Research conclusions provide a basis for the implementation of NZEB and LCZEB. In this study, relevant data from the other literature were used to calculate the embodied energy. Future studies should calculate the embodied energy using local statistic data to increase its accuracy.

\section{Acknowledgements}

This work was supported by the National Natural Science Foundation of China under the project No. 51268020 and Applied Basic Research Program Foundation of Yunnan Province under the project No. 2011 FZ024.

\section{REFERENCES}

[1] Ji, Y. C., Lomas, K. J., \& Cook, M. J. (2009). Hybrid ventilation for low energy building design in south China. Building and Environment, 44(11), 2245-2255. https://doi.org/10.1016/j.buildenv.2009.02.015

[2] Torcellini, P. A., \& Crawley, D. B. (2006). Understanding zero-energy buildings. ASHRAE Journal, 48(9), 62-69.

[3] Building Energy Conservation Center of Tsinghua University. (2018). 2018 Annual report on China building energy efficiency. Beijing, China: China Architecture \& Building Press.

[4] Azeroual, M., Makrini, A. E., Moussaoui, H. E., \& Markhi, E. H. (2018). Renewable energy potential and available capacity for wind and solar power in Morocco towards 2030. Journal of Engineering Science and Technology Review, 11 (1), 189-198. https://doi.org/10.25103/jestr.111.23 
[5] Stephan, A., Crawford, R. H., \& Myttenaere, K. D. (2013). A comprehensive assessment of the life cycle energy demand of passive houses. Applied Energy, 112, 23-34. https://doi.org/10.1016/j.apenergy.2013.05.076

[6] Schniedersa, J. \& Feista, W. (2015). Ludwig Rongen. Passive houses for different climate zones. Energy and Buildings, 105, 71-87. https://doi.org/10.1016/j.enbuild.2015.07.032

[7] Feist, W. (2006). Definition of passive houses. Darmstad, Germany: Passivhaus Institute.

[8] Hernandez, P. \& Kenny, P. (2010). From net energy to zero energy buildings: Defining life cycle zero energy buildings (LC-ZEB). Energy and Buildings, 42(6), 815-821. https://doi.org/10.1016/j.enbuild.2009.12.001

[9] Crawley, D., Pless, S., \&Torcellini, P. (2009). Getting to net zero. ASHRAE Journal, 51, 18-25.

[10] Berggrena, B., Hallb, M., \& Walla, M. (2013). LCE analysis of buildings - Taking the step towards Net Zero Energy Buildings. Energy and Buildings, 62(5), 381-391. https://doi.org/10.1016/j.enbuild.2013.02.063

[11] Moghaddam, I. G., Saniei, M., \& Mashhour, E. (2018). A multi-slack optimization model for scheduling energy hubs in smart Grids. Journal of Power Technologies, 98(3), 287295. Retrieved from http://papers.itc.pw.edu.pl/index.php/ $\mathrm{JPT} /$ article/view/828

[12] Zhou, Z. Y., Zhou, L., Zhu C., \& Ebert, A. (2016). Establishing energy consumption quota for residential buildings using regression analysis and energy simulation. Journal of Engineering Science and Technology Review, 9(6), 103-107. https://doi.org/10.25103/jestr.096.14

[13] Iqbal, M. T. (2004). A feasibility study of a zero energy home in Newfoundland. Renewable Energy, 29 (2), 277-289. https://doi.org/10.1016/S0960-1481(03)00192-7

[14] Wang, L. P., Gwilliam, J., \& Jones, P. (2009). Case study of zero energy house design in UK. Energy and Buildings, 4l(11), 1215-1222. https://doi.org/10.1016/j.enbuild.2009.07.001

[15] Eshraghi, J., Narjabadifam, N., Mirkhani, N., Khosroshahi, S. S., \& Ashjaee, M. (2014). A comprehensive feasibility study of applying solar energy to design a zero energy building for a typical home in Tehran. Energy and Buildings, 72, 329-339. https://doi.org/10.1016/j.enbuild.2014.01.001

[16] Pikas, E., Thalfeldt, M., Kurnitski, J., \& Liias, R. (2015). Extra cost analyses of two apartment buildings for achieving nearly zero and low energy buildings. Energy, 84, 623-633. https://doi.org/10.1016/j.energy.2015.03.026

[17] Tian, X. D. (2017). Research on the design of nearly zero energy residential buildings in Guanzhong rural areas. Master Thesis, Xi'an University of Architecture and Technology.

[18] Sun, Z. Q. (2018). Research on the design of Zero Energy Office Building. Master Thesis, Xi'an University of Architecture and Technology.

[19] Li, C. (2018). Research on feasibility of net zero energy residential buildings in Beijing. Master Thesis, Harbin Institute of Technology.

[20] Feng, G. H., Xu, X. L., \& Wu, S. (2017). Application of nearzero energy building technology system in severe cold region. Building Science, 33(6), 15-20 https://doi.org/10.13614/j.cnki.11-1962/tu.2017.06.03

[21] Stephan, A. \& Stephan, L. (2016). Life cycle energy and cost analysis of embodied, operational and user-transport energy reduction measures for residential buildings. Applied Energy, 161, 445-464. https://doi.org/10.1016/j.apenergy.2015.10.023

[22] Leckner, M. \& Zmeureanu R. (2011). Life cycle cost and energy analysis of a net zero energy house with solar combisystem. Applied Energy, 88(1), 232-241.

https://doi.org/10.1016/j.apenergy.2010.07.031
[23] Atmaca, A. \& Atmaca, N. (2015). Life cycle energy (LCEA) and carbon dioxide emissions ( $\left.\mathrm{LCCO}_{2} \mathrm{~A}\right)$ assessment of two residential buildings in Gaziantep, Turkey. Energy and Buildings, 102, 417-431. https://doi.org/10.1016/j.enbuild.2015.06.008

[24] Feng, Y. K. (2012). Life cycle assessment of solar water heater. Master Thesis, Southeast University.

[25] Bai, J. B. (2015). PV system based on the LCA energy analysis theory. Master Thesis, Xi'an University of Architecture and Technology.

[26] Liu, Y. B., Wang, X. T., Lin, B. R., \& Peng, B. (2011). Research progress in life cycle energy consumption data of building subassembly and equipment. Building Science, 27, 255-262. https://doi.org/10.13614/j.cnki.11-1962/tu.2011.s2.025

[27] Gong, X. Z. (2012). A comparative study on life cycle energy consumption of residential buildings. Intelligent Buildings \& City Information, 8, 14-18. https://doi.org/10.13655/j.cnki.ibci.2012.08.018

[28] Poortinga, W., Steg, L., \& Vlek, C. (2003). Household preferences for energy-saving measures: A conjoint analysis. Journal of Economic Psychology, 24(1), 49-64. https://doi.org/10.1016/S0167-4870(02)00154-X

[29] Hipolito-Ojalvo, F., Roncero-Clemente, C., HorrilloHorrillo, L., \& Carmona-Fernandez, D. (2018). Nearly zero energy building (NZEB): A review of definitions and identification of the energy balances by means of simulation. DYNA, 93(1), 36-40. https://doi.org/10.6036/8285

\section{Contact information}

\section{Zhiyong ZHOU, Associate Professor}

(Corresponding author)

Faculty of Civil Engineering and Mechanics,

Kunming University of Science and Technology,

Room 429, No. 727 Jingming South Road,

Kunming City, Yunnan Province, 650500, China

E-mail: zhiy_zhou@163.com

\section{Xiaochen ZHANG}

Faculty of Civil Engineering and Mechanics,

Kunming University of Science and Technology,

Room 429, No. 727 Jingming South Road,

Kunming City, Yunnan Province, 650500, China

E-mail: zzyybyb0724@sina.com

Jia LU

School of Business, SEGI University, Selangor, Malaysia

B1-25-12, Casa Residence, JalanTeknologi 2/1D, Signature Park, Kota

Damansara, Petaling Jaya, Selangor, 47810, Malaysia

E-mail: lukelo01213@gmial.com

\section{Jiangang HUANG}

Yunnan Kelun Engineering Quality Inspection Co., Ltd.

Economic Development Zone,

Kunming City, Yunnan Province, 650500, China

E-mail:18288914497@163.com

\section{Li ZHOU}

Faculty of Civil Engineering and Mechanics,

Kunming University of Science and Technology

Room 429, No. 727 Jingming South Road,

Kunming City, Yunnan Province, 650500, China

E-mail: jollychou123@163.com

\section{Yiqin HE}

Faculty of Civil Engineering and Mechanics,

Kunming University of Science and Technology,

Room 429, No. 727 Jingming South Road, Kunming City, Yunnan Province, 650500 , China

E-mail: Heyiqin517@163.com 